\title{
Are there any natural resources?
}

Peter G. Brown, PhD

School of Environment and the Departments of Geography and Natural Resource Sciences

McGill University 3534 University Street

Montréal, Québec

H3A 2 A7

Canada

peter.g.brown@mcgill.ca

AвSTRACT. Local and regional environments have for many centuries been seen as, or as being composed of, "natural resources," which have generally been considered fully available for human use, irrespective of any use to which other species, purposefully or not, might put them. The global environment has more recently, though less routinely, been seen in this way. I examine full-human-use arguments in three widely credited philosophical traditions: the Judeo-Christian-liberal, the Aristotelian-Cartesian-rationalist, and the utilitarian or neoclassical economic. I find each tradition's full-human-use argument unsatisfactory. I then discuss, and ultimately recommend, an alternative, an all-species-use argument based on Albert Schweitzer's much admired but seldom adopted reverence-for-life ethic. I find revealed by this alternative argument a previously unnamed good, one worthy of honor, protection, and enlargement; I call this good "the commonwealth of life." In conclusion, I consider important implications of accepting commonwealth-of-life reasoning, including foundational changes in ethics.

ABRÉGÉ. L'environnement, local et régional, est perçu depuis des siècles comme un ensemble de " ressources naturelles ", généralement considérées comme étant à l'entière disposition de l'homme, sans tenir compte de l'usage que d'autres espèces pourraient, intentionnellement ou non, en faire. Plus récemment, l'environnement, à l'échelle mondiale, est aussi perçu de cette façon bien que moins systématiquement. J'examine d'abord les arguments à l'appui d'un usage tout humain des ressources en fonction de trois traditions philosophiques bien acceptées: judéo-chrétienne-libérale, aristotélique-cartésienne-rationaliste et utilitariste ou néoclassique économique. J'en conclus que ces arguments sont insatisfaisants, et cela, pour chacune de ces traditions. Je propose ensuite et recommande finalement une autre approche, un argument à l'appui d'un usage toutes espèces fondé sur la philosophie, largement admirée mais rarement adoptée, d'Albert Schweitzer, qui prône le respect de la vie. Selon moi, cet argument révèle un bien jusqu'ici non nommé, un bien qui mérite d'être honoré, protégé et élargi; je le nomme le «bien commun de la vie ». En conclusion, j'examine les implications importantes d'accepter ce principe de bien commun de la vie, y compris les changements fondamentaux conséquents pour l'éthique.

$\mathrm{I}$ $s$ the natural world a reservoir of resources for human gratification? The philosophers' answer, assuming one answer could be tallied reliably from many traditions over millennia of scholarship, would surely be yes, and by a wide margin.

Should we accept this answer as inevitable? Or has it been the rarely questioned premise making casually respectable an ever-more-audacious "power grab" by nature's one philosophizing species - to the detriment of many, most, or all other species? If the latter, and I assert that the latter more fairly suggests the truth, then how can we understand and resolve the problem into which we have led ourselves? This paper proposes a way.

\section{Property in three traditions}

What establishes legitimate property rights to things in the world not made by humans? What is "property" 


\section{Brown}

in natural resources? Are there any "natural resources" at all?

"Property" implies three clusters of rights. First, rights of exclusion, as in the right to keep others off, or away from, property. Second, rights of use, as in the right to do what one wishes to do with property. And, third, rights of disposition, as in rights to sell, give, or otherwise transfer property. In current institutional arrangements, property can be owned by one or more individuals, by groups such as tribes or clans, by legal entities such as corporations, or by nations, such as Egypt or the United States. How these concepts are understood in practice differs across societies. Importantly, property can be owned portions of the earth itself; lands, riverbeds, waters, and even airspace can be owned. Alternatively, and in contrast, property can be the benefit stream arising from these portions of owned earth, as in a "usufruct" right, whereby the "fruits" of land or water - such as deer or fish or volumes of a river's flow - are possessed.

Anthropocentric thinking about natural resources is natural enough; we could hardly expect ourselves spontaneously to develop a fungal, arboreal, avian, or equine view. Justifying self-centeredness is another matter, however. In the philosophical West, three interrelated traditions have offered partially overlapping justifications for thinking that the world belongs to persons. These are the Judeo-Christian-liberal, the Aristotelian-Cartesian-rationalist, and the utilitarian or neoclassical economic.

\section{The Judeo-Christian-liberal tradition}

Particularly influential has been a British philosopher, John Locke, who accepted the Bible as authoritative, the world as a gift from God to humanity, and human beings as created in the image of God. On the matter of the gift he wrote: "The earth, and all that is therein, is given to men for the support and comfort of their being." ${ }^{1}$ And on being created in the divine image: "God makes him in his own image after his own Likeness, makes him an intellectual Creature, and so capable of Dominion." ${ }^{2}$ To these assumptions he added what he took to be a self-evident truth, that each person had ownership of his or her own body, though all ultimately were owned by God. We had a natural right to our bodies and to what we did with our bodies, provided we did not harm others and did not contradict God's laws as to the use of that "property" of the body, such as eating unholy foods, or engaging in sexual practices considered abominations. We established property rights over things in the world by mixing what we already owned - the labor of our own bodies - with what we did not own. For example, if we shot it, skinned it, and cooked it, then a deer belonged to us because we had mixed our labor with it. Similarly, if we enclosed a forest and converted it into farmland, thereby presumably increasing its usefulness to humanity, we could own the land itself. These ideas constituted "the labor theory of value," which in turn made plausible the establishment, distribution, redistribution, and defense of property without appeal to royal charter - without royalty at all, for that matter. Indeed, Locke's attitude toward monarchy was paralleled by his attitude toward aristocracy in general and toward wealth; contrary to the conservatives who would claim him as a proto-libertarian, Locke unquestionably saw property rights as subordinate to naturallaw obligations. For instance, "[T]would always be a sin for any man of estate to let his brother perish for want of affording him relief out of his plenty." 3

Locke argued that we can take from the commons "as God ... hath given the world to men in common" only if there is "enough and as good" left for others. ${ }^{4}$ This condition has often been called "the Lockean proviso." Taking land from the commons increased the resource base because cultivated land was so much more productive of what humans needed than was land in its natural state. Indeed, Locke saw an obligation to convert nature to human use so as to fulfill the naturallaw obligation to "preserve all mankind." Converting a swamp to farmland helped avoid malnutrition, and, intuitively enough even in seventeenth-century medical thought, disease. The privatization of property satisfied Locke's proviso as long as the commons, the source of all surplus, remained undepleted. Moreover, the proviso could be satisfied even when all land had been appropriated, as long as gainful employment was created and surplus food generated.

The acceptance of money as a medium of exchange facilitated the conversion of waste into assets, as it created incentives to produce for distant markets. Farms in North America could produce grain for Europe, since barter was unnecessary, bringing additional assets "on line" in discharging our natural-law obligations. Yet, though he thought it necessary for complex civilizations such as his own, Locke saw money as a curse as much as 


\section{Are there any natural resources?}

a blessing. Previously, acquiring more than could be consumed before spoilage was hardly possible, but money made this quite possible, and great inequalities developed; our natural law obligations thus came to include redistribution. Money helped eliminate the waste of nature by increasing incentives for nature's conversion, but money also increased the waste of humanity by permitting over- and under-consumption and increasing opportunities for the indulgence of fancy.

Liberal moral philosophers in this tradition had trouble enough scaling the heights of monarchy. They were struggling to plant the flag of human rights above the reach of privilege and manipulation; other-thanhuman rights remained below, as in the writings of Immanuel Kant, who famously accorded nature no moral standing whatsoever. A core liberal concern became the distribution of humans' rights to nature's other-than-human bounty. Only in the nineteenth century would the interrelatedness of these rights start to be asserted.

\section{The Aristotelian-Cartesian-rationalist tradition}

Another source of the doctrine that "humanity owns the earth" was Aristotle, though he did not offer an explicit theory of property. While he characteristically emphasized the continuity of mankind and nature, Aristotle also emphasized differences. As he observed in the Metaphysics, "the animals other than man live by appearances and memories, and have but little connected experience; but the human race lives also by art and reasoning." 5 The humanity-owns-the-earth tradition reached its zenith, or nadir, with René Descartes, who, among others, considered the ability to think the essential character of being human. He saw the rest of the world as "extension," as the taking up of space. Something could be either a thing or a mind. Descartes regarded other animals as things, "devoid of reason," 6 or automata, acting out a mechanical destiny without cognition. This was a view, though put in different vocabularies, that has been carried forward by many others who consider the behavior of nonhuman animals to be determined exclusively, or at least very largely, by instincts or genetic programs. For these AristotelianCartesian rationalists, all the world is an object to be used by humans - the only "subjects" - however humans wish.
The utilitarian or neoclassical economic tradition

Philosophical utilitarianism, which has come to be equated with the view that human preferences are the main unit of value, arose in response to the problems flowing out of the Protestant Reformation. Nearly continuous disputes, including religious wars, were fueled by an unfamiliar variety of beliefs about right and wrong, a variety attributable to a great divergence in moral premises. Utilitarianism was put forward as a common denominator for moral judgment.

Jeremy Bentham, in his 1789 book, An Introduction to the Principles of Morals and Legislation, had insisted that not only human beings but also any other form of life capable of suffering had to be included in moral calculations. John Stuart Mill joined Bentham in considering nonhuman animals: "Granted that any practice causes more pain to animals than it gives pleasure to man; is that practice moral or immoral? And if, exactly in proportion as human beings raise their heads out of the slough of selfishness, they do not with one voice answer 'immoral,' let the morality of the principle of utility be forever condemned."7 But despite such forceful declarations, J. S. Mill focused on the wellbeing of humans almost exclusively. The fundamental goal, he wrote, was the "greatest happiness of the greatest number." Every person's happiness counted equally, and actions had to be planned with this equality in mind. "The equal claim of everybody to happiness ... involves an equal claim to all the means of happiness." 8 Property was to be allocated and governed so as to produce the greatest possible grand total amount of human happiness. Utilitarianism's legacy discipline, microeconomics, preserves this all-human perspective. Indeed, when microeconomic techniques, including cost-benefit analysis, came to be applied in "animal science," they led, ironically, to the consideration of nonhuman animals only insofar as human owners and consumers were concerned. J. S. Mill's sentiment aside, nonhuman animals - a group including coral but excluding trees - have secured no moral standing through any calculation of "happiness."

\section{Difficulties}

These traditions each assumed that the world was made for humanity. Thus, they neatly explained teleological explanations are nothing if not neat - the 


\section{Brown}

fit between human needs and earthly offerings, with the "fall of man" explaining any mismatch. This assumption was most explicit in Locke, who quoted scripture in support of his views. It was carried forward, less explicitly, in rationalism and utilitarianism. While not wholly irreconcilable with religious belief, modern science is sharply at variance with this particular account of humanity's relationship to the world. Rather than being explained as the work of God, the fit of needs and offerings is credited to adaptive co-evolution.

There is no empirical evidence that the world was made for humanity, and no hypothesis that it was can be falsified. Nor do we account for our intellect by citing its similarity to God's but as one among many complex products of our evolution. Locke, by way of his larger argument against absolutism, recognized some duties to what he called the "inferior creatures." He stressed that our dominion over them was like that of a shepherd over his flock, and that, while given to mankind in common, they were ultimately God's property, just like the rest of the world. ${ }^{9}$ Hence, we had duties to refrain from wasting inferior creatures and to treat them with respect; this latter duty Locke did not explain further.

These traditions - with Bentham excepted and Mill suggestive - have taught that humanity, owing to distinctions of mind, differs in kind from the rest of nature. From a theological point of view, humanity had been created in the image of God. From an empirical point of view, nonhuman species had been programmed genetically, their actions those of automata. Today, we know better. Similarities between us and other species are fundamental and numerous. Most tellingly, the reasoning mind is not limited to primates or even chordata. Bees, for example, act intelligently as well as automatically. ${ }^{10}$ We can no longer easily accept Descartes' view that the world of "subjects" is limited to persons and the world of matter defined by "extension." Nonhuman animals must be credited with intelligence, emotion, and sensation.

Anthropocentricity, the sine qua non of humanism, has become less and less satisfying in philosophy, even in utilitarianism. Anthropocentricity still dominates casual moralizing, clinical ethics, legal reasoning, and - most fatefully of all - microeconomics, but elsewhere its distorting effects have become sufficiently apparent to force it out of fashion. In environmental philosophy, anthropocentricity is mainly a dead letter; utilitarianism lives on, however, despite its failure to offer a satisfactory account of the foundations of moral obligation. This failure can be traced to embedded paradoxes.

The principle of utility appears to be one principle, but it contains two variables - happiness and its wide distribution - each of which we are supposed to maximize. It is impossible to maximize both at the same time, so we need a third rule about the management of conflict. But no third rule is supplied.

To add to these difficulties, in offering no place for the language of rights - Bentham referred to rights as "nonsense, nonsense on stilts" — utilitarianism authorizes the ruthless exploitation of the minority, or even a relatively powerless majority, if we can show a net gain of total utility. Numerous attempts to rescue utilitarianism from this defect, by arguing that we can reconstruct the language of rights out of summary rules, have failed to persuade. ${ }^{12}$ We still must decide whether any particular action will maximize utility if it overrides the rule. ${ }^{13}$ Rule utilitarianism always collapses to act utilitarianism, and the rescue attempt fails. Much of modern "resource" economics tries to distance itself from the failures of utilitarianism by dropping the language of utility in favor of the language of preferences or tastes. Yet, if preferences and tastes are not connected to utility, then left completely mysterious is why one should care about them or why one should care about them on behalf of strangers.

Finally, a utilitarian should consider the well-being of at least some nonhuman animals, since some of these surely think, feel pleasure, and feel pain. A retreat to tastes and preferences worsens this anthropocentric problem considerably and leads to many absurd judgments. For example, in the logic of such a theory, earthworms would reveal a post-precipitation preference for sidewalks as contrasted with soil by crawling out of the latter and onto the former. Once we recognize the revelation of this preference, should we not endeavor to satisfy it? Within the utilitarianism of Bentham, yes indeed; within the utilitarianism of neoclassical economists, certainly not - unless that answer would affect a human utility function, which it might, given the biomass of earthworms and their importance to agriculture, gardening, and lawn care. 


\section{Are there any natural resources?}

If one does adopt utilitarianism, one may as well side with Bentham. In An Introduction to the Principles of Morals and Legislation, 1781, he wrote:

The day may come, when the rest of the animal creation may acquire those rights which never could have been withholden from them but by the hand of tyranny. The French have already discovered that the blackness of the skin is no reason why a human being should be abandoned without redress to the caprice of a tormentor [...See Lewis XIV's Code Noir.] It may come one day to be recognized, that the number of the legs, the villosity of the skin, or the termination of the os sacrum, are reasons equally insufficient for abandoning a sensitive being to the same fate. What else is it that should trace the insuperable line? Is it the faculty of reason, or, perhaps, the faculty of discourse? But a fullgrown horse or dog is beyond comparison a more rational, as well as a more conversable animal, than an infant of a day, or a week, or even a month, old. But suppose the case were otherwise, what would it avail? [T] he question is not, Can they reason? nor, Can they talk? but, Can they suffer? ${ }^{14}$

The anthropocentric assumptions of the resource economics literature are entirely ad hoc. The attempt to include nature in the calculus by coming up with monetary values for "ecosystem services" fails to find an exit from the metaphysical myopia of the mainstream view. ${ }^{15}$ An argument offered in favor of this approach is that when the monetary value of "nature" is set high, then attention is called to the high cost of ignoring nature. While it appeals rhetorically, this argument perpetuates a false view of humanity's place in the world and legitimates and extends a practice already much too common: trying to reduce every thing and every one to market terms. Of the millions of nonhuman species in the world, why all should be in service to man is not explained.

The ecosystem-services idea may in part be a holdover from the belief that humans were created in the image of God and thus were entitled to unique - or at least special - moral consideration. That this exceptionalist belief is now under widespread reconsideration, both in theological circles and from the perspective of evolutionary biology, has not been taken into account in utilitarianism or neoclassical economics, wherein the wellbeing of nonhumans remains a concern only indirectly, as a function of human utility. That nonhuman animals or ecosystems could be of noninstrumental value, having value in their own rights, is not considered.

What we seek, and what I anticipate in the framework sketched below, is a broad "constitution of the world" in which considerations of utility play a subordinate, yet still robust, role.

\section{"Natural resources" re-evaluated}

Is ours the only species fairly able to claim air, water, territory, and other necessities of life? This question, which in few cultures would ever have been taken seriously in the past, is no longer wholly unaskable, even in law. The Endangered Species Act and the Species at Risk Act in the United States and Canada, respectively, were steps away from old presumptions, yet these bills might have been seen as mere elaborations on an old humanity-as-proprietor theme had they not departed from mainstream conceptions of privacy, property, and rights. Propertyrights groups, whose reactions were and remain strongly negative, certainly recognized the departure as real.

Materially more ambitious have been attempts to repair ecological damage already done: attempts to restore salmon, condors, wolves, and so forth, to their former habitats. Significant, but radically insufficient, amounts of marine and terrestrial habitat have been set aside for particular species - or, in practice, for any species other than Homo economicus. Though the reasons for these set-asides have often included human wellbeing, including supposedly "sustainable" benign forms of commerce, such as eco-tourism, they have also included the wellbeing of other species in their own right.

Progress is grudgingly deliberate and far from slowing even the acceleration of anthropogenic extinctions, but clearly now progress is possible. Once we began walking the road of evolutionary, classical-genetic, and molecular-genetic understanding, the moral boundary between others and us began to blur. The world of human "subjects" and natural "objects" cannot be seen from or reached through science, whose modern lessons point in parallel more surely to "primitive" teachings, wherein peoples assumed themselves to be subjects among subjects. We have had to readjust our self-image, as Aldo 


\section{Brown}

Leopold wrote, "from conqueror of the land-community to plain member and citizen of it." ${ }^{16}$ That said, our analytical capacity and our moral imagination make for us a responsibility that no other species shares or, as far as we can tell, even recognizes. This responsibility is hard to summarize, hard to square with our evolution as omnivorous, grasping materialists. Albert Schweitzer described this responsibility by its requirement, "reverence for life," 17 a compellingly beautiful idea, both hopeful and poignant, immediate and remote, with myriad implications, many quite clear, yet some not clear at all.

Schweitzer sought the origin of his own demonstrably extraordinary conscientiousness, even the origin of moral motivation generally. When he felt - felt - he had found it, he set about to persuade civilization, then collapsing in vanity and war, and civilization's philosophers, deeply implicated in worldwide catastrophe, that he had found a principle well worth their consideration. He was steaming upstream, literally, in 1915:

Lost in thought I sat on the deck of the barge, struggling to find the elementary and universal conception of the ethical which I had not discovered in any philosophy. Sheet after sheet I covered with disconnected sentences, merely to keep myself concentrated on the problem. Late on the third day, at the very moment when, at sunset, we were making our way through a herd of hippopotamuses, there flashed upon my mind, unforeseen and unsought, the phrase "Reverence for Life." The iron door had yielded: the path in the thicket had become visible. ${ }^{18}$

Reverence-for-life was not sentimentalism but a disposition, not a refusal to use the living world but a respectful affirmation of humanity's place within it, responsibility for it, and responsibility to it.

Schweitzer's approach was risky, susceptible as it was to dismissal as ethical intuitionism. You can safely claim the primacy of your intuitions, and I can safely claim the primacy of mine, as our two primacies cannot reliably be ordered or reconciled. Schweitzer realized this and sought corroboration in every source he knew.

First, reverence-for-life seemed a natural extension of the teachings of Jesus, particularly the two great commandments, as it helped align humanity with the spirit of divine love and broadened "neighbor" beyond persons to all living things.
Second, reverence-for-life was a "philosophy of the will," similar in kind to nineteenth- and early twentiethcentury works of Nietzsche, Schopenhauer, Bergson, and Goethe, and also to prominent precepts of Hinduism. Similar in kind, yes, because most fundamentally around us we find the will to live, but reverence-for-life was hardly similar in content - or, most obviously in the case of Nietzsche, intent. All these antecedents Schweitzer faulted: they were self-centered, incomplete, or escapist.

Third, reverence-for-life shared with moral-philosophical contributions of Adam Smith and David Hume an emphasis on the role of sympathy, the ability to look at the world from another's point of view. But Schweitzer argued that sympathy went beyond pointof-view to the sharing of feelings and experience; sympathy was an extension of the self in the direction of the creative will of the universe.

Fourth, reverence-for-life was a source, not a product, of rational argument. It was, in this sense, then, mystical, and respectably so, as had been the activist evangelism of Paul the Apostle, whose career Schweitzer would analyze formally between the wars. ${ }^{19}$ Reverence-for-life was a mysticism through which the self was not lost but enriched, the individual not suppressed but situated within an ultimately deathless whole.

Fifth, reverence-for-life was consistent with Darwin's argument, in The Descent of Man, that all differences between persons and other life forms were matters of degree, not of kind. Any attempt to draw a boundary of morality between humans and other species would fail. Darwin's picture hung above Schweitzer's desk.

I accept this idea - reverence-for-life — as foundational but unfinished, and I propose to build upon it a capstone concept: the commonwealth of life.

\section{Resource use in "the commonwealth of life"}

From the commonwealth-of-life perspective, most "natural resources" are already being used, either by persons or by members of nonhuman species.

Canada is often said to have a fresh-water surplus, but this statement can make sense only from an anthropocentric point of view. All the fresh water in Canada - and everywhere else, too - is in reality already used, if not in every respect expended, in support of natural communities. Minerals within the 


\section{Are there any natural resources?}

earth's crust might be thought an exception, unless they supported subterranean organisms, as my colleague Frédéric Fabry has pointed out. Leaving unexplored any potential sympathies for "the deep subterranean biosphere," we are tempted to accept the use of minerals as untroubling for a commonwealth-of-life morality. But extraction raises more than the material, and commonwealth-of-life considerations come quickly into play. Deeply buried coal, though a product of Carboniferous life, may not now be bosting life, but its extraction, whether by shaft mining, strip mining, open-cast mining, or mountain-top removal, does affect life, drastically, through the leaching of associated substances, especially sulfur, through interactions with air and water, through the dispersal of particulates, through aerosolization of combustion products, and so on.

Then does a commonwealth-of-life morality oppose all human activity, all industry, all improvement? No, nor does it oppose digging by ants, chewing by beavers, gathering by bees, recycling by fungi, or flowering by dandelions. The difference between the commonwealth-of-life view and the standard anthropocentric view is a disagreement about resource scarcity. From the former perspective, all resources are already used; from the latter, resources increase only as anthropocentricity increases. Debates about scarcity are as much about metaphysical premises as about factual conditions.

So, how do we decide which human uses legitimately trump which nonhuman uses in which circumstances?

First, we should notice that legitimacy's burden of proof has been rebalanced. Human use must be supported by reasons, and the reasons offered cannot be concerned solely with human wellbeing. In the commonwealth of life we find obligations - human-tononhuman, if not consciously or enforceably the other way around as well - just as in political liberalism we find obligations that are human-to-human exclusively: noninterference and redistribution, for example.

Of course, what counts as a "reason," or as reasonable, is hard to establish. The dominance of the anthropocentric view guarantees that the wellbeing of nonhuman species will seem irrelevant, or at best instrumental to policy, except insofar as human industries are affected or human sentiments aroused. Arguments based on two of the three moral foundations of property considered above, the exception being
Bentham's own original utilitarianism, explicitly assume this view, made all the more convincing by portrayal of nonhumans as automata - an early-modern characterization readily updated over the centuries to suit scientific advancement.

Second, the pre-analytical vision of the western rational tradition screens out much of what we need to learn and consider; cultural anthropology and study of the world's religions can help restore it. ${ }^{20}$ The taking of life and the use of resources on which life depends must occur reverently, which is to say thoughtfully and appreciatively. Many of the world's traditions, quaintly anachronistic though they may seem, have much to teach on environmental stewardship, attitudinally at least: nature and life as gifts, hunted animals as objects of respect, land and water as common homes.

While they have helped create much of our present problem, western religious traditions do offer compensatory concepts: humanity's obligation to care for God's creation, which the Book of Genesis tells us God found to be "very good"; ${ }^{21}$ an Old Testament notion of right relationship with land; ${ }^{22}$ and transcendental unity of self and universe - antithesis of the dualism that fated us to impasse.

Third, we must recognize that life takes life, whether directly or indirectly. Killing, resource use, and environmental alteration are inevitable, though not inevitably brazen. So, how should we think about killing and killing's variants? Here is how Harvey Feit summarized the traditional attitude toward hunted animals in the Cree culture of the James Bay region of Quebec. The animal killed in the hunt was considered a gift:

The balance is reciprocal, and in return for the gifts, the hunter has obligations to the animals and chuetenshu (the north wind) to act responsibly. He is expected to completely use what he is given, to act respectfully toward the bodies and souls of the animals by observing the highly structured procedures for retrieving the animal, butchering it, consuming its flesh, and disposing of its remains. It is expected that men will kill animals swiftly, and avoid causing them undue suffering. It is also understood that men have the skill and technology to kill many animals, too many, and it is part of the responsibilities of the hunter not to kill more than he is given, and not to "play" with animals by killing then for fun or self-aggrandizement. ${ }^{23}$ 


\section{Brown}

This is a usufruct view of property. The hunters here were taking only what the land produced reliably in the long run. But the land's spontaneous productivity, and the sea's, cannot sustain a densely peopled world, even one whose citizens hope to improve their own behavior, nor can spontaneous productivity sustain the surplus needed to make, inter alia, science. Reverence-for-life for lives lived in a commonwealth of life - must be a reservoir of practical ideas. Or it will fairly be dismissible as all aspiration and no implication.

\section{What to do?}

Schweitzer is often criticized for failing to provide much guidance on how actually to implement his ethic. His own decisions seemed ad hoc. He fed dozens of fish to his pet pelican. He gave detailed instructions on how to get a snake that "stole" eggs to strangle itself on wire. Being Alsatian, he ate sausage.

Consider an analogy with pacifism. The pacifist is often confronted by the critic with a dilemma: kill the men who are threatening your citizens or let the citizens be killed. To this the pacifist replies, "I am not primarily concerned with what to do about these dilemmas when they arise, but I am concerned with preventing them from arising to begin with. So my emphasis is on disarmament, institutions such as a world court, and opting out of the war system."

Reverence-for-life was an admonition to live life so as to minimize such dilemmas, in number, in seriousness, and in consequence.

Standing, as he does, with the whole body of living creatures under the law of this dilemma ... in the willto-live, man comes again and again into the position of being able to preserve his own life and life generally only at the cost of other life. If he has been touched by the ethic of Reverence for Life, he injures and destroys life only under a necessity, which he cannot avoid, and never from thoughtlessness. So far as he is a free man he uses every opportunity of tasting the blessedness of being able to assist life and avert it from suffering and destruction. $^{24}$

We were being urged, first, to reconceptualize our behavior; second, to reform our institutions; and, third, to build a civilization deserving respect. Nothing less. The first task was hard enough, but also clear. Its accomplishment universally could never have been expected, and the safest bet was always that no progress along the prescribed line would ever occur. But progress has occurred, nowhere enough to satisfy, but far too much to support a total-futility claim. Schweitzer's second task has also been undertaken; indeed, many thousands worldwide now find careers in reformed institutions or in new institutions based on reformed ideas. Yet, progress along this second task's main front has slowed, right where the full-human-use argument meets the all-species-use argument.

To understand why, we might round up the usual suspects: economic interests opposing progressive change, monochromatic perspectives of mainstream journalists, difficulties organizing large numbers of people to further a diffuse cause. But the reasons are deeper, reaching to the sources of our traditions. Traditions which, as Schweitzer pointed out, assume the good is the human good and leave the rest of the biosphere in shadow. So, his argument comes full circle.

If we are to care for the commonwealth of life, we must care about the source of life's capacity for selforganization and maintenance. We find that source dutifully obeying all physical laws; one of these, the second law of thermodynamics or "entropy law," has special meaning for ethics. It suggests new ways to think about old responsibilities, setting us on a path toward Schweitzer's goal: a civilization worthy of respect.

Complex life is an exception in the universe; whether it be a frequent exception or an absolute rarity or a unique terrestrial endowment none yet can say confidently. ${ }^{25}$ The universe as a whole is entropic conforming to the second law's insistence about the degradation of energy and the tendency toward uniform simplicity. On earth, for billions of years now, life has been swimming against the tide, an eddy of complexity in a gathering sea of simplicity, all made possible, but never certain, by core heating and continuous exogenous inputs of solar energy captured by plants and converted into what we call nature. Energy degrades in the process, but a surplus arrives daily. Menacing the commonwealth of life now is anthropogenic multifocal ecological simplification, a dismantling of natural complexity at the system level, if not the organismal, demonstrably faster than sunlight, photosynthesis, and DNA can compensate. Preservation of the capacity for self-organization and maintenance - formally, preser- 


\section{Are there any natural resources?}

vation of the global anti-entropic capacity - must underlay our ethics.

How much of the endowment making self-organization possible belongs to mankind? A widely noted estimate has put human consumption of the products of terrestrial photosynthesis at around forty percent. ${ }^{26}$ With Homo sapiens just one of thirteen- to fifteenmillion species, this seems a bit much. Over half the grain grown in North America is fed to livestock and only then as meat, milk, and eggs to humans, a practice requiring vast acreages of simplified plantings. Imagine the flourishing of life foregone. We should leave substantial self-organizational scope for the other living things with whom we "share the light," or, as Locke might have applied his proviso in an environmentally aware era, we should leave them "enough and as good."

The hallmark of our membership in the commonwealth of life should be the health of the ecosphere: what Aldo Leopold called "land." Since he knew health was hard to define, Leopold began with its opposite. He said the symptoms of land sickness were "abnormal erosion, abnormal intensity of floods, decline of yields in crops and forests, decline in carrying capacity ..., a general tendency toward the shortening of species lists and of food chains, and a world wide dominance of plant and animal weeds." ${ }^{27}$ Seen from this perspective, the highest and best use of land is not what will bring the greatest economic return but what will bring resilient flourishing of life and the maintenance of capacity for self-renewal. Human uses of land dominated by economic considerations must be seen in the context of the wellbeing of the landscape as a whole. For the earth as a whole, preservation of self-organizational capacity must trump traditional economic arguments.

The commonwealth-of-life idea invites us to notice, as Schweitzer did in text and life alike, that we reside in two spheres: the transcendent and the temporal. We identify as a matter of course with ourselves and with the whole of which we are a part, a fact well appreciated by J. S. Mill - though forgotten by his intellectual progeny. We are participants in what James Carse has called "an infinite game," as contrasted with a finite game, like baseball, with set boundaries in space and time, unchangeable rules during the game, and definite winners and losers. ${ }^{28}$ "In the infinite game, to play is to win." 29 Those who are better at playing help those not so adept, both directly and through institutional adaptation conscientiously considerate of a long and fruitful future. ${ }^{30}$ We would look, like Schweitzer, "right through death" "31 toward life, flowering and abundant.

I wish to thank Christian Abizaid, Hannah Askew, David Brown, Ethan Brown, Philip Buckley, Margaret Forrest, Eric Freyfogle, Blad Hansen, Peter Jacobs, Dan Levitin, Rodney Mark, Greg Mikkelson, Catherine Moore, Timothy Moore, Jim Nicell, Don Smith, Stuart Smith, and anonymous reviewers for critical and constructive comments. Defects are my own.

\section{References}

1. John Locke, Two Treatises of Government, Peter Laslett, ed. (Cambridge: Cambridge University Press, 1960), Second Treatise, $\mathbb{} 26$.

2. Ibid, First Treatise, $\mathbb{} 30$.

3. Ibid, First Treatise, $\mathbb{} 42$.

4. Ibid, Second Treatise, $\mathbb{} 33$.

5. Aristotle, Metaphysics, Book A (1), Lines 25-7.

6. René Descartes, Automatism of Brutes in Selections (New York: Charles Scribner's Sons, 1927) p. 360.

7. John Stuart Mill, "Whewell on Moral Philosophy," in John Stuart Mill and Jeremy Bentham: Utilitarianism and Other Essays (Middlesex: Penguin, 1987) p. 253.

8. John Stuart Mill, "Utilitarianism," in Essential Works of John Stuart Mill (New York: Bantam Matrix, 1965)

p. 247.

9. Locke, First Treatise, $\mathbb{} 39$.

10. D. R. Griffin, Animal Minds (Chicago: University of Chicago Press, 1992).

11. Jeremy Bentham, "Anarchial Fallacies; Being an Examination of the Declaration of Rights Issued During the French Revolution," in Works of Jeremy Bentham, John Bowring, ed., Volume II (New York: Russell \& Russell, 1962) Article II, p. 501.

12. Henry Sidgwick, The Methods of Ethics [1874], 7th ed., reissue (Chicago: University of Chicago Press, 1962).

13. J. J. C. Smart, and B. Williams, Utilitarianism - For and Against (Cambridge: Cambridge University Press, 1973), pp. 100-107.

14. Jeremy Bentham, An Introduction to the Principles of Morals and Legislation (1781), Chapter XVII: Of the Limits of the Penal Branch of Jurisprudence; $\mathbb{\$} 2$. Jurisprudence, its branches; XXIX, 2.

15. Robert Costanza et al., Nature, 387, 15 May 1997, pp. 253-260.

16. Aldo Leopold, A Sand County Almanac (New York: Oxford University Press, 1989), p. 204.

17. Albert Schweitzer, Out of My Life and Thought (New York: Henry Holt and Company, 1933) p. 186. 


\section{Brown}

18. Ibid, p. 185.

19. Albert Schweitzer, The Mysticism of Paul the Apostle [1931] (Baltimore: Johns Hopkins University Press, 1998).

20. Colin Scott, "Science for the West, Myth for the Rest? The Case of James Bay Cree Knowledge Construction," in Naked Science: Anthropological Inquiry into Boundaries, Power, and Knowledge, Laura Nader, ed. (New York: Routledge, 1996), pp. 69-86.

21. Matthew Scully, Dominion: The Power of Man, the Suffering of Animals and the Call to Mercy (New York: St. Martin's Press, 2002).

22. Herman E. Daly John B. Cobb, Jr., For the Common Good (Boston: Beacon Press, 1989), pp. 102-5.

23. Harvey A. Feit, "Waswanipi Cree Management of Land and Wildlife: Cree Ethno-Ecology Revisited," in Native

People, Native Lands: Canadian Indians, Inuit and Metis, B. Cox, ed. (Ottawa: Carlton University Press, 1992), pp. 75-91.
24. Schweitzer, Out of My Life and Thought, p. 272.

25. Peter D. Ward Donald Brownlee, Rare Earth: Why Complex Life is Uncommon in the Universe (New York: Copernicus, 2000).

26. P. M. Vitousek, et al., "Human Appropriation of the Products of Photosynthesis," BioScience 36:6, June 1986, pp. 368-373.

27. Aldo Leopold, "The Land-health Concept and Conservation" in For the Health of the Land: Previously Unpublished Essays and Other Writings, J. Baird Callicott and Eric T. Freyfogle, eds. (Washington: Island Press, 1999) p. 219.

28. James Carse, Finite and Infinite Games (New York: The Free Press, 1986).

29. Stewart Brand, The Clock of the Long Now (New York: Basic Books, 1999), p. 187.

30. Ibid, p. 161.

31. Ibid, p. 147. 